\title{
Differential investment in body girths by sex: evidence from 3D photonic scanning in a Thai cohort
}

\begin{tabular}{|r|l|}
\hline Journal: & American Journal of Physical Anthropology \\
\hline Manuscript ID & AJPA-2016-00321.R2 \\
\hline Wiley - Manuscript type: & Research Article \\
\hline Date Submitted by the Author: & n/a \\
\hline Complete List of Authors: & $\begin{array}{l}\text { Shirley, Meghan; University College London, Childhood Nutrition Research } \\
\text { Centre, Great Ormond Street Institute of Child Health } \\
\text { Cole, Tim; University College London, Population, Policy and Practice } \\
\text { Programme, Great Ormond Street Institute of Child Health } \\
\text { Charoensiriwath, Supiya; National Electronics and Computer Technology } \\
\text { Center } \\
\text { Treleaven, Philip ; University College London, Department of Computer } \\
\text { Science } \\
\text { Wells, Jonathan; University College London, Childhood Nutrition Research } \\
\text { Centre, Great Ormond Street Institute of Child Health }\end{array}$ \\
\hline Key Words: & trade-offs, sexual dimorphism, adipose tissue, lean mass, interaction term \\
\hline $\begin{array}{r}\text { Subfield: Please select your } \\
\text { first choice in the first field.: }\end{array}$ & $\begin{array}{l}\text { Human biology [living humans; behavior, ecology, physiology, anatomy], } \\
\text { Theory }\end{array}$ \\
\hline &
\end{tabular}


Differential investment in body girths by sex: evidence from 3D photonic scanning in a Thai cohort

Meghan K Shirley, Tim J Cole, Supiya Charoensiriwath, Philip Treleaven and Jonathan CK Wells

UCL Great Ormond Street Institute of Child Health

London WC1N 1EH UK

Text pages plus bibliography: 20

Number of figures: 2

Number of tables: 5

Abbreviated title: Human sexual dimorphism in tissue investment

Key words: trade-offs, sexual dimorphism, adipose tissue, lean mass, interaction term

For proofs:

Professor Jonathan Wells

Childhood Nutrition Research Centre, $4^{\text {th }}$ Floor

UCL Great Ormond Street Institute of Child Health

30 Guilford Street

London WC1N 1EH, UK

jonathan.wells@ucl.ac.uk

02079052104 


\section{ABSTRACT}

Objectives: Life history trade-offs may manifest between competing organs and tissues in the body. Sexual dimorphism in tissue investment is well-established in humans, with sexassociated body shape differences linked to natural and sexual selection. This study uses threedimensional (3D) photonic scanning to test whether males and females differentially invest energy in various body regions in relation to two independent proxies of growth.

Materials and Methods: Body shape data (multiple girths) came from a Thai cohort ( $n=11,610$; $53 \%$ female; age range 21-88 years). Weight was considered a proxy for recent energy acquisition. Stature represented completed growth, a proxy for energy acquisition earlier in life. The data were analyzed using growth-proxy by sex interaction log-log regression models adjusting for age, salary and number of children.

\section{Results: For a given percentage increase in weight, females showed greater percentage increases than males in girths of the arm, chest, hip, thigh, knee and calf ( $p<.001$ ), whilst males exceeded females in head and waist girths (also $p<.001$ ). For a given percentage increase in height, weight and all girths showed greater proportional changes in males than females $(p<$ $.001)$.}

Discussion: These results indicate sex-specific life history strategies wherein the direction and timing of energy investment in girths varies between the sexes. The results add to literature suggesting that sexual dimorphism in body morphology is not a fixed trait; rather, differential energy allocation to specific body regions appears to be a plastic strategy adjusted in relation to energy acquisition across the life course. 


\section{Introduction}

Life history theory predicts that organisms use energy captured from the environment in ways which promote survival and reproduction. Assuming energy is finite, the optimization of energy investment strategies is characterized by a series of trade-offs, where resources used for one function are unavailable for allocation to others (Stearns, 1992; Hill, 1993; Ellison, 2003). In contemporary human populations, rising levels of overweight and obesity indicate that many individuals do not overtly lack energy; nevertheless, how energy is allocated for functional purposes may still reflect trade-offs that evolved in past environments.

Energy trade-offs have largely been examined in the anthropological literature in relation to essential functions like growth, reproduction, maintenance and immune defense (Kirkwood and Rose, 1991; Hill and Kaplan, 1999; Charnov, 2001; Tracer, 2002). However, trade-offs may also manifest in the construction of the body, for example between competing organs and tissues, and these trade-offs may vary based on environmental conditions and across the life course (see Aiello and Wheeler, 1995; Isler and van Schaik, 2006; Wells, 2010, 2013; Pomeroy et al., 2012; Kotrschal et al., 2013). It is well-established that mammals demonstrate sexual dimorphism in tissue investment, yet humans appear to do so in a manner different to other animals, including their close primate relatives (Pond, 1978, 1998; Norgan, 1997; Wells, 2007). Marked contrasts are apparent in human body shape due to variation in the deposition of fat and lean tissues, even when BMI is similar (e.g. Wells et al., 2007).

Explanations for human body shape dimorphism, which are not mutually exclusive, include the differential exposure of the sexes to natural selective pressures, and sexual selection (Darwin, 1871; Lande, 1980; Gaulin and Sailer, 1984; Fairbairn, 1997; Olsson et al., 2002; Plavcan, 2001, 2012; Wells, 2007). Zillikens et al. (2008) identified genetic differences between males and females for body composition variables including percentage fat and lean mass. Waist-to-hip ratio (WHR), an index of fat distribution that is heritable independently of BMI, also 
demonstrates sex-specific effects at a number of loci (Heid et al., 2010; Shungin et al., 2015). At the same time, core genes controlling growth are shared by males and females, and the sexes' ontogenetic divergence in morphology may principally arise through sex-specific gene expression (Badyaev, 2002). The characteristics of dimorphism can vary over time and in association with cultural preferences or ecological conditions, indicating that phenotypic plasticity is also relevant (Norgan, 1990; Holden and Mace, 1999; Teder and Tammaru, 2005; Deaton, 2008; Guntupalli and Moradi, 2008; Wells, 2012; Freedman and Ford, 2015).

At birth, human females have on average slightly less lean mass (here used synonymously with fat-free mass) and slightly more fat than males (Tanner, 1990; Rodriguez et al., 2004; Andersen et al., 2013). Whilst males continue to accrete lean tissue through to early adulthood (Marshall and Tanner, 1968; Maynard et al., 2001, Wells et al., 2012a), from puberty females preferentially invest in peripheral adipose tissue, a strategy attributed to their primary role in funding reproduction and lactation (Rebuffé-Scrive et al., 1985; Foley and Lee, 1991; Lee, 1996; Dufour and Sauther, 2002; Ellison, 2003; Lassek and Gaulin, 2006, 2009).

Gonadal steroid hormones and growth hormone are central to the sexually dimorphic distribution of adipose tissue, whilst testosterone is especially important in males' accretion of lean mass in adolescence (Tanner, 1965; Martin and Daniel, 1993; Bogin, 1999; Rogol et al., 2002). Hormones and transcription factors may interact at sexually-dimorphic loci, like those described above for WHR, to differentially impact on the regulation of gene activity (Shungin et al., 2015). Regional variability in the action of the enzyme lipoprotein lipase may also be important for sex-specific fat distribution on the body (Norgan, 1997).

That males demonstrate greater overall lean mass than females has been shown in diverse populations (Immink et al., 1992; Deurenberg et al., 1995, 2001; Deurenberg-Yap et al., 2000; Maynard et al. 2001), and this investment strategy may have been shaped by aggressive male:male competition for mates (Trivers, 1972; Pagel, 1994; Hawkes, 2004; Dixson, 2009; Lassek and Gaulin, 2009; Puts, 2010; Plavcan, 2012). In an examination of data across several 
populations, males on average had $18 \%$ greater lean mass than females, who in contrast had $34 \%$ more fat mass than males, after adjusting for height (Wells, 2006). Unlike in females, sex steroid hormones in males mediate increased fat storage on the trunk (Norgan, 1997; Santosa and Jensen, 2014) where it may promote immune function (Gabrielsson et al., 2003; Wells and Cortina Borja, 2013).

Sexual dimorphism likewise extends to skeletal morphology. From puberty, sex hormones drive differential skeletal development in males and females, and bone mineral content, size and mass are often increased in males, resulting in relatively larger skeletal elements and overall body size compared to females (Riggs et al., 2002; Wells, 2007). However, certain aspects of skeletal growth, for example in the pelvis, are greater in females than males (Schultz, 1949; Tague, 2005).

These components of dimorphism likely have two main implications for fitness: they allow the sexes to prioritize different physiological functions, especially regarding reproduction, and they also allow them to signal in different ways to the opposite sex. Females may signal their capacity to nourish offspring via both quantity and pattern of fat deposition. Muscle mass might signal a male's capacity to attract mates and produce offspring with similar reproductive potential (Zaadstra et al., 1993; Singh, 1993; Norgan, 1997; Ellison, 2003; Wells, 2006; Lassek and Gaulin, 2008, 2009).

The extent to which sexual dimorphism arises through genetic mechanisms or plastic responses to ecological circumstances at different life stages is still inadequately understood. Rather than dimorphism being 'fixed' at adulthood, there is evidence that it continues to change through adult life (Gallagher et al., 1997; Wells et al., 2007, 2008; Shen et al., 2009). It is therefore especially informative to consider dimorphism in tissue trade-offs as a function of energy acquisition at different points in the life course. 
On this basis, we hypothesize that the two sexes invest in body girths differently, in association with energy acquired relatively recently (proxied by current weight) or during development (proxied by stature, representing completed linear growth). Given the evidence for shape dimorphism described above, we hypothesize that males preferentially invest energy in building a bigger body overall, in particular during early development when fat-free mass is most readily accreted. In contrast, we hypothesize that females preferentially invest in reproductive fat stores, especially during adolescence and adulthood. During adult life, fat is relatively more plastic than lean. We therefore expect associations between girths and height to be stronger in males, and those between girths and weight to be stronger in females.

To test these hypotheses, we used body shape data derived from three-dimensional (3D) photonic scanning. Previous analysis of a large British cohort found contrasting associations between body girths and height in men and women (Wells et al., 2007). Here, we use similar 3D scan data from the Thai National Sizing Survey, and include an interaction term in multivariable regression analyses to further elucidate patterns of sexual dimorphism in association with energy supply at different life course stages. To our knowledge, this is the first study to investigate in men and women the potential statistical interaction of sex and height, and also sex and weight, on various girths of both the trunk and limbs.

\section{MATERIALS AND METHODS}

The Size Thailand survey was conducted in Thailand from 2006-2007 (Charoensiriwath and Tanprasert, 2010) to obtain information on body size and shape in the Thai population. The data and methods have been described previously (e.g. Wells et al., 2011, 2012b). Briefly, data were collected using a single $[\mathrm{TC}]^{2}$ body scanner (Cary, North Carolina, USA; www.tc2.com) transported between five geographical regions (Bangkok, North, South, Northeast and Central). Individuals from 74 of 76 Thai provinces ultimately took part. No information on ethnicity was recorded, although participants were required to show proof of Thai nationality in order to participate. 
Recruitment utilized quota sampling based on age, gender and geographical region, and reached potential participants through advertisements including flyers, websites, and TV and radio interviews. Transport was provided from rural areas to scanning sites, where data collection centers were set up. A minimum number of males and females were recruited within set age cells: $17-25,26-35,36-45,46-59$ and $60+$ years, with an age range of 17-88 years. Information on number of children, medical history, and salary was collected via questionnaire. Salaries ranged from 5,000 baht (USD 140) to >40,000 baht (USD 1140) per month. Exclusion criteria included pregnancy, disabilities, and lack of proof of Thai nationality. Participants gave written consent for their data to be analyzed and published in anonymized form.

Participants were scanned in a standardized position, with feet shoulder-width apart and arms held out from the sides of the body at a $45^{\circ}$ angle. They wore tight-fitting underwear to avoid artefacts of bulky clothing. The scanner projects strips of safe, white light onto the body, and computer algorithms reconstruct skin surface topography from a raw point cloud of photonic data (Douros et al., 1999; Treleaven, 2004). [TC] ${ }^{2}$ Body Measurement System Software version 5.3 was used to automatically extract a number of measurements, with technical precision within $0.5 \mathrm{~cm}$, from each scan. Those used in this analysis were girths of the head, mid-upper arm, chest, waist (taken at the level of the small of the back), hip, mid-thigh, knee and calf, along with manually measured weight and height. Limb measurements were on the right-hand side.

Compared to manual anthropometry, 3D scans tend to overestimate girths due to differences in the manner of acquisition and the location of landmarks (Wells et al., 2007). However, epidemiological analyses are unlikely to be confounded by this problem, as previous studies have reported high correlations and excellent consistency in ranking between the two techniques (Wang et al., 2006; Wells et al., 2011, 2012b).

John Wiley ${ }^{7} \&$ Sons, Inc. 


\section{STATISTICS}

Body girths, height and weight were natural log transformed to capture the allometric relationships between the variables. Correlations were calculated between the girths, weight and height in each sex. The data were plotted to visualize sex differences in the associations of each girth with weight or height.

Two sets of multivariable regression models were fitted, with each body girth as a separate outcome. The first set included as covariates sex, height and their interaction, while the second set included sex, weight and their interaction. Weight was also analyzed as an outcome in the first set of models. Weight and height were mean-centered prior to analysis, to ensure that their main effects did not confound the interaction term. Due to the log transformations, the interaction terms tested for differences between males and females in the percentage difference in each girth associated with a one percent difference in height or weight. In the presence of the interaction term, the corresponding main effect coefficient for height or weight corresponded to that for females.

In addition, the models controlled for age, salary and fertility as potential confounders. Age was analyzed as a continuous variable; salary was coded as a binary variable designating two groups: $\leq 10,000$ or $>10,000$ baht/month, and fertility was based on the number of children categorized as $0,1,2,3$ or 4 children in both sexes, and additionally, 5 and $6+$ children in women, or $5+$ children in men.

Statistical analyses were carried out using SPSS (IBM SPSS Statistics for Macintosh, Version 24.0) and the R language and environment for statistical computing (Version 1.0.136), with two-tailed tests for significance at an alpha level of 0.05 .

\section{RESULTS}

John Wiley $\stackrel{8}{\&}$ Sons, Inc. 
Analyses were conducted on 11,610 individuals ( $53 \%$ female). Those $<21$ years old $(n=774,48 \%$ female) and possibly not yet at final height were excluded, hence the age range for analysis was 21 to 88 years (females: range=21-88, median=41, IQR=30-54; males: range=21-88, median=40.5, IQR=30-52). Raw values for body size and shape outcomes are shown in Table 1. Means and standard deviations for height, weight, BMI and eight girths stratified by sex and six age categories are given in Table 2.

[Table 1 and 2 near here]

Correlations of weight and height with body girths are shown in Table 3. Head girth, unlike the other girths, was only weakly correlated with weight in both sexes, while hip had the strongest relationships with weight.

[Table 3 near here]

Girth-height correlations were generally weaker than girth-weight correlations in both sexes. In males, waist was most weakly correlated with height $(r=0.13)$, while in females, waist girth $(r=$ -0.04) and chest girth $(r=0.04)$ were both very weakly correlated. In general, the girth-height correlations were more sexually dimorphic than the girth-weight correlations.

Plots of height versus body girths illustrate the sex differences, with males having steeper slopes than females for all girths (Fig. 1, and Supporting Information).

[Figure 1 near here]

Plots for weight and body girths are more mixed, with interactions evident for some girths, but not others. Where the interactions are apparent, they are smaller than for height. Head-weight and waist-weight plots demonstrate steeper slopes for males, whilst male and female slopes in the calf-weight plot are virtually identical (see Supporting Information). For arm, chest, and

John Wiley $\stackrel{9}{\&}$ Sons, Inc. 
knee plots, slopes are steeper for females than males to varying degrees (Fig. 2, and Supporting Information). Hip and thigh plots show relatively consistent sex differences across the whole range of weight, whereas the slopes show very little contrast between the sexes (Fig. 2).

[Figure 2 near here]

Table 4 shows multivariable log-log regression models of body girth, and also weight, on the interaction between sex and height, adjusting for sex, height, age, number of children, and salary. (Fuller results including the age, salary and fertility variables are available online as Supporting Information, Table S1). In each model, the interaction term tested for sexdependent variation in the relationship between the girth (or weight) and height. This term was positive and highly significant in every model $(p<.0001)$. Thus, males demonstrated a larger percentage difference in every girth and in weight for a given percentage difference in stature, compared to females. The largest interaction coefficients were for arm and waist, and the smallest for head and knee.

[Table 4 near here]

Table 5 (and Supporting Information, Table S2) shows similar models for body girths on sexweight interactions, controlling for sex, weight, age, number of children and salary. Again, all the interaction terms were highly significant $(p<.0001)$. For head and waist the terms were positive, indicating that males had a larger percentage difference for a given percentage difference in body weight, compared to females. For the other girths the interactions were negative and the reverse was true. Arm and knee girth had the largest interactions, and hip girth the smallest.

[Table 5 near here] 
Adding to the models information on salary and number of children did not appreciably alter the coefficients for the other variables, including the interaction term, and $R^{2}$ values remained largely unchanged. Thus, these variables are not interpreted further. For information, unadjusted values are given online for weight, height, BMI, and all shape variables stratified by sex and number of children (Supporting Information, Table S3), along with unadjusted values for the same variables stratified by sex and salary (Supporting Information, Table S4).

\section{DISCUSSION}

Optimized reproduction is the fundamental factor in any organism's successful life history strategy (Ellison, 2003), and male/female dimorphism in the amount and distribution of fat and lean tissue is functionally relevant to mating and producing offspring (Norgan, 1997; Wells, 2010). Consistent with this, dimorphism becomes distinctly more marked from puberty, remains highly pronounced throughout the reproductive years (Boot et al., 1997; Norgan, 1997; Maynard et al., 2001; Nindl et al., 2002; Wells, 2006, 2007), and then declines in old age (Wells et al., 2008). This pattern is evident across ethnic and cultural groups (Immink et al., 1992; Deurenberg et al., 1995, 2001; Deurenberg-Yap et al., 2000; Maynard et al. 2001). Previous analyses of British 3D scan data reported significant sex-differences in body shape, indicating strategic, sex-specific investment in different tissues (Wells et al., 2007).

With the incorporation of interaction terms in regression analyses, we were able to investigate statistically whether, as hypothesized, the relationship between a given girth and height or weight differs in a sex-dependent manner (Aiken and West, 1991). Our results constitute evidence for such sex-interactive effects with both height and weight on girth outcomes. These findings support the notion of distinct life history strategies in males and females, wherein both the direction and timing of investment in body girths differs between the sexes.

Individuals demonstrate a wide scatter about the regression lines, particularly in girth-height plots (Fig. 1), within which we focus on average male and female effects. In Figure 1, it appears that investment in the arm and chest is similar for shorter and taller women, in comparison to starker differences between shorter and taller men. Taller men have larger waists than shorter John Wiley ${ }^{11} \&$ Sons, Inc. 
men, but for women the reverse is true. Regression analysis reveals that for a given percentage increase in height, a proxy for energy acquisition in early life, males invest in girths and overall weight to a greater degree than females. This is consistent with males' differential accretion of lean tissue during development (Marshall and Tanner, 1968; Maynard et al., 2001), through which they may increase muscle mass and body size to facilitate successful competition for mates in adulthood (e.g. Hawkes, 2004; Lassek and Gaulin, 2009; Puts, 2010).

Muscle mass is increased in males relative to females (Fuller et al., 1992; Shih et al., 2000; Abe et al., 2003), most notably in the upper body. Evidence suggests the combination in males of a broad chest, wide shoulders and narrow waist enhances females' perception of male attractiveness (Maisey et al., 1999; Fan et al., 2005), although this may vary between urban and rural populations (Swami and Tovée, 2005). This was reflected in our sex-height interaction analyses, where weight as an outcome demonstrated the largest coefficient, followed by upperbody girths including the arm and chest, along with the thigh.

In contrast, in association with a given percentage increase in weight, Thai females appear to invest more than males in all girths except the head and waist. Here, we considered weight a proxy for more recent energy acquisition, more likely to represent an increase in adipose tissue. Fat is clearly essential to both sexes as an energy store, and a central component of immune function (Gabrielsson et al., 2003; Fantuzzi, 2005; Wells and Cortina-Borja, 2013). However, for both its overall amount and regional distribution, fat appears to be a key sexually-selected trait in females, in contrast to the greater lean mass favored in males (Singh, 1993; Lassek and Gaulin, 2008; 2009). Beyond other functions, fat provides energy for reproductive women, especially during lactation (Clutton-Brock et al., 1989; Dufour and Sauther, 2002).

Several maternal fat depots (e.g. girths of the chest, arm, thigh and calf) have been linked with offspring birth weight, indicating that energy stores throughout the body may benefit reproductive investment (Neggers et al., 1995; Gupta et al., 2001). Females in our sample appear to favor several body girths for a given increase in weight relative to males, with the

John Wiley 12 Sons, Inc. 
greatest effect for the arm, followed by the knee and thigh. However, interaction coefficients in the sex-weight models are smaller than those in the sex-height models.

Females demonstrate preferential deposition of fat around the hips, buttocks and thighs, referred to as gluteofemoral fat (Lassek and Gaulin, 2006, 2008), although males have relatively larger hip bones and bi-iliac breadth (Kurki, 2011). Contrary to expectations, we did not find that females invest relatively more in hip and thigh girths in association with increasing weight. Rather, we observed a relatively fixed degree of dimorphism in these girths across the whole of the weight range, as shown by the large coefficients for male sex in the models. For the hip in particular, this may relate both to preferential fat deposition by females, and also to larger pelvic canal dimensions (Tague, 1992; Kurki, 2011). Since males showed greater investment in hip girth than females in association with height, this may indicate that greater female investment in pelvic dimensions occurs during/after puberty, consistent with evidence that pelvic dimensions of women continue to increase through this period (see Moerman, 1982).

In the sex-weight models, most interaction coefficients indicated a larger proportional increase in a given girth for females, relative to males. However, the interaction coefficient in the waist girth model showed the reverse. This result is inconsistent with the notion of sexual selection for an 'inverted triangle' shape (broad chest and shoulders, narrow waist) in males (Maisey et al., 1999; Fan et al., 2005; Swami and Tovée, 2005). Instead, it suggests sex differences in the distribution of fat tissue. Studies indicate that visceral adipose tissue (VAT) increases in both sexes with age, but beyond this males have greater VAT depots compared to females (Lemieux et al., 1993; He et al., 2004; Kuk et al., 2005; Shen et al., 2009).

We incorporated in our models a fertility variable principally to control for the confounding effects of parity on females, in whom associations between shape and parity have been demonstrated (Lassek and Gaulin, 2006; Wells et al., 2010; Wells et al., 2011). Similar associations have not been found for males, although evidence suggests that the hormone testosterone is lower in married fathers (Berg and Wynne-Edwards, 2001; Gray et al., 2002;

John Wiley 13 Sons, Inc. 
Gray et al., 2006; Gettler et al., 2011). Testosterone impacts on tissue distribution (Norgan, 1997), thus it is not unreasonable that fatherhood could impact on shape (Wells et al., 2011), although further data are needed to elucidate these possible effects.

\section{The large sample size is a principal strength of this study; statistical power to detect interaction}

effects is smaller than for main effects (McClelland and Judd, 1993; Brookes et al., 2004; Durand, 2013). The data were collected using a single scanner following a standardized protocol. Limitations include the cross-sectional nature of the data; for example, a proxy for energy acquisition in early life was used in the absence of available body shape data from adolescent individuals who would have been experiencing developmental trade-offs in real time. We were unable to address potential mechanisms that might underlie tissue trade-offs (e.g. the action of hormones). Additionally, with this methodology we were not able to attribute energy investment specifically to fat, lean, or other tissues, or investigate potential differences in investment related to BMI. These represent outstanding questions for future work.

In conclusion, our findings of sex-interactive effects with height and weight on body girths indicate that males and females invest energy differently across competing parts of the body at different points in the life course. The present results are consistent with the notion that sexual dimorphism is a plastic strategy varying in association with developmental experience and ecological conditions. Further studies are required in additional populations in order to elucidate these findings in more detail.

\section{LITERATURE CITED}

John Wiley 14 Sons, Inc. 
Abe, T., Kearns, C.F., \& Fukunaga, T. (2003). Sex differences in whole body skeletal muscle mass measured by magnetic resonance imaging and its distribution in young Japanese adults. British Journal of Sports Medicine, 37, 436-440.

Aiello, L.C., \& Wheeler, P. (1995). The expensive tissue hypothesis: The brain and the digestive system in human and primate evolution. Current Anthropology, 36, 199-221.

Aiken, L.S., \& West, S.G. (1991). Multiple regression: testing and interpreting interactions. Newbury Park, CA: Sage.

Andersen, G.S., Girma, T., Wells, J.C.K., Kaestel, P., Leventi, M., Hother, A., Michaelsen, K.F., \& Friis, H. (2013). Body composition from birth to 6 mo of age in Ethiopian infants: Reference data obtained by air-displacement plethysmography. American Journal of Clinical Nutrition, 98, 885894.

Badyaev, A.V. (2002). Growing apart: An ontogenetic perspective on the evolution of sexual size dimorphism. Trends in Ecology and Evolution, 17, 369-378.

Berg, S.J., \& Wynne-Edwards, K.E. (2001). Changes in testosterone, cortisol, and estradiol levels in men becoming fathers. Mayo Clinic Proceedings, 76, 582-592.

Bogin, B. (1999). Patterns of human growth. Cambridge: Cambridge University Press.

Boot, A.M., Bouquet, J., de Ridder, M.A.J., Krenning, E.P., \& de Muinck Keizer-Schrama, S.M.P.F. (1997). Determinants of body composition measured by dual-energy X-ray absorptiometry in Dutch children and adolescents. American Journal of Clinical Nutrition, 66, 232-238.

Brookes, S.T., Whitely, E., Egger, M., Smith, G.D., Mulheran, P.A., \& Peters, T.J. (2004). Subgroup analyses in randomized trials: risks of subgroup-specific analyses; power and sample size for the interaction test. Journal of Clinical Epidemiology, 57, 229-236.

Charnov, E.L. (2001). Evolution of mammal life histories. Evolutionary Ecology Research, 3, 521535.

Charoensiriwath, S., \& Tanprasert, C. (2010). An overview of 3D body scanning applications in Thailand. Presented at the International Conference on 3D Body Scanning Technologies, Lugano, Switzerland.

Clutton-Brock, T.H., Albon, S.D., \& Guinness, F.E. (1989). Fitness costs of gestation and lactation in wild mammals. Nature, 337, 260-262.

Darwin, C. (1871). The Descent of Man, and Selection in Relation to Sex. London: John Murray.

Deaton, A. (2008). Height, health and inequality: The distribution of adult heights in India. American Economic Review, 98, 468-474. 
Deurenberg, P., Wolde-Gebriel, Z., \& Schouten, F.J. (1995). Validity of predicted total body water and extracellular water using multifrequency bioelectrical impedance in an Ethiopian population. Annals of Nutrition and Metabolism, 39, 234-241.

Deurenberg, P., Andreoli, A., Borg, P., Kukkonen-Harjula, K., De Lorenzo, A., van Marken Lichtenbelt, W.D., Testolin, G., Vigano, R., \& Vollaard, N. (2001). The validity of predicted body fat percentage from body mass index and from impedance in samples of five European populations. European Journal of Clinical Nutrition, 55, 973-979.

Deurenberg-Yap, M., Schmidt, G., van Staveren, W.A., \& Deurenberg, P. (2000). The paradox of low body mass index and high body fat percentage among Chinese, Malays and Indians in Singapore. International Journal of Obesity, 24, 1011-1017.

Dixson, A.F. (2009). Sexual Selection and the Origins of Human Mating Systems. Oxford: Oxford University Press.

Douros, I., Dekker, L., \& Buxton, B.F. (1999). Reconstruction of the surface of the human body from 3D scanner data using B-splines. Proceedings SPIE, 3640, 234-245.

Dufour, D.L., \& Sauther, M.L. (2002). Comparative and evolutionary dimensions of the energetics of human pregnancy and lactation. American Journal of Human Biology, 14, 584-602.

Durand, C.P. (2013). Does raising Type I error rate improve power to detect interactions in linear regression models? A simulation study. PLOS ONE, 8, e71079.

Ellison, P.T. (2003). Energetics and reproductive effort. American Journal of Human Biology, 15, 342-351.

Fairbairn, D.J. (1997). Allometry for sexual size dimorphism: pattern and process in the coevolution of body size in males and females. Annual Review of Ecology and Systematics, 28, 659-687.

Fan, J.T., Dai, W., Liu, F., \& Wu, J. (2005). Visual perception of male body attractiveness. Proceedings of the Royal Society of London B, 272, 219-226.

Fantuzzi, G. (2005). Adipose tissue, adipokines, and inflammation. Journal of Allergy and Clinical Immunology, 115, 911-919.

Foley, R.A., \& Lee, P.C. (1991). Ecology and energetics of encephalization in hominid evolution. Philosophical Transactions of the Royal Society B, 334, 223-232.

Freedman, D.S., \& Ford, E.S. (2015). Are the recent secular increases in the waist circumference of adults independent of changes in BMI? American Journal of Clinical Nutrition, 101, 425-431. 
Fuller, N.J., Laskey, M.A., \& Elia, M. (1992). Assessment of the composition of major body regions by dual-energy X-ray absorptiometry (DEXA), with special reference to limb muscle mass. Clinical Physiology, 12, 253-266.

Gabrielsson, B.G., Johansson, J.M., Lönn, M., Jernås, M., Olbers, T., Peltonen, M., Larsson, I., Lönn, L., Sjöström, L., Carlsson, B., \& Carlsson, L.M.S. (2003). High expression of complement components in omental adipose tissue in obese men. Obesity Research, 11, 699-708.

Gallagher, D., Visser, M., De Meersman, R.E., Sepúlveda, D., Baumgartner, R.N., Pierson, R.N., Harris, T., \& Heymsfield, S.B. (1997). Appendicular skeletal muscle mass: Effects of age, gender, and ethnicity. Journal of Applied Physiology, 83, 229-239.

Gaulin, S.J.C., \& Sailer, L.D. (1984). Sexual dimorphism in weight among the primates: the relative impact of allometry and sexual selection. International Journal of Primatology, 5, 515535.

Gettler, L.T., McDade, T.W., Feranil, A.B., \& Kuzawa, C.W. (2011). Longitudinal evidence that fatherhood decreases testosterone in human males. Proceedings of the National Academy of Sciences, 108, 16194-16199.

Gray, P.B., Kahlenberg, S.M., Barrett, E.S., Lipson, S.F., \& Ellison, P.T. (2002). Marriage and fatherhood are associated with lower testosterone in males. Evolution and Human Behavior, 23, 193-201.

Gray, P.B., Yang, C-F.J., \& Pope, Jr., H.G. (2006). Fathers have lower salivary testosterone levels than unmarried men and married non-fathers in Beijing, China. Proceedings of the Royal Society $B, 273,333-339$.

Guntupalli, A.M., \& Moradi, A. (2008). What does gender dimorphism in stature tell us about discrimination in rural India, 1930-1975? In M.B. Pal, B. Ghosh, \& T.S. Vasulu (Eds.), Gender and Discrimination: Health, Nutritional Status, and Role of Women in India (pp. 258-277). New Delhi, India: Oxford University Press.

Gupta, V., Hatwal, S.K., Mathur, S., Tripathi, V.N., Sharma, S.N., Saxena, S.C., \& Khadwal, A. (2001). Calf circumference as a predictor of low birth weight babies. Indian Pediatrics, 33, 119120.

Hawkes, K. (2004). Mating, parenting and the evolution of human pair bonds. In B. Chapais \& C.M. Berman (Eds.), Kinship and behavior in primates (pp. 443-473). Oxford: Oxford University Press.

He, Q., Horlick, M., Thornton, J., Wang, J., Pierson, R.N., Heshka, S., \& Gallagher, D. (2004). Sexspecific fat distribution is not linear across pubertal groups in a multiethnic study. Obesity Research, 12, 725-733. 
Heid, I.M., Jackson, A.U., Randall, J.C., Winkler, T.W., Qi, L., Steinthorsdottir, V., ... Lindgren, C.M. (2010). Meta-analysis identifies 13 new loci associated with waist-hip ratio and reveals sexual dimorphism in the genetic basis of fat distribution. Nature Genetics, 42, 949-960.

Hill, K. (1993). Life history theory and evolutionary anthropology. Evolutionary Anthropology, 2, 78-88.

Hill, K., \& Kaplan, H. (1999). Life history traits in humans: Theory and empirical studies. Annual Review of Anthropology, 28, 397-430.

Holden, C., \& Mace, R. (1999). Sexual dimorphism in stature and women's work: A phylogenetic cross-cultural analysis. American Journal of Physical Anthropology, 110, 27-45.

Immink, M.D., Flores, R., \& Diaz, E.O. (1992). Body mass index, body composition and the chronic energy deficiency classification of rural adult populations in Guatemala. European Journal of Clinical Nutrition, 46, 419-427.

Isler, K., \& van Schaik, C. (2006). Costs of encephalization: The energy trade-off hypothesis tested on birds. Journal of Human Evolution, 51, 228-243.

Kirkwood, T.B.L., \& Rose, M.R. (1991). Evolution of senescence: Late survival sacrificed for reproduction. Philosophical Transactions of the Royal Society B, 332, 15-24.

Kotrschal, A., Rogell, B., Bundsen, A., Svensson, B., Zajitschek, S., Brännström, I., Immler, S., Maklakov, A.A., \& Kolm, N. (2013). Artificial selection on relative brain size in the guppy reveals costs and benefits of evolving a larger brain. Current Biology, 23, 168-171.

Kurki, H.K. (2011). Pelvic dimorphism in relation to body size and body size dimorphism in humans. Journal of Human Evolution, 61, 631-643.

Lande, R. (1980). Sexual dimorphism, sexual selection and adaptation in polygenic characters. Evolution, 34, 292-305.

Lassek, W.D., \& Gaulin, S.J.C. (2006). Changes in body fat distribution in relation to parity in American women: A covert form of maternal depletion. American Journal of Physical Anthropology, 131, 295-302.

Lassek, W.D., \& Gaulin, S.J.C. (2008). Waist-hip ratio and cognitive ability: Is gluteofemoral fat a privileged store of neurodevelopmental resources? Evolution of Human Behavior, 29, 26-34.

Lassek, W.D., \& Gaulin, S.J.C. (2009). Cost and benefits of fat-free muscle mass in men: Relationship to mating success, dietary requirements, and native immunity. Evolution of Human Behavior, 30, 322-328. 
Lee, P.C. (1996). The meanings of weaning: Growth, lactation and life history. Evolutionary Anthropology, 5, 87-96.

Lemieux, S., Prud'homme, D., Bouchard, C., Tremblay, A., \& Després, J-P. (1993). Sex differences in the relation of visceral adipose tissue accumulation to total body fatness. American Journal of Clinical Nutrition, 58, 463-467.

Maisey, D.M., Vale, E.L.E., Cornelissen, P.L., \& Tovée, M.J. (1999). Characteristics of male attractiveness for women. Lancet, 353, 1500.

Marshall, W.A., \& Tanner, J.M. (1968). Growth and physiological development during adolescence. Annual Review of Medicine, 19, 283-300.

Martin, A.D., \& Daniel, M. (1993). Regional adiposity and the sex hormones. In W. Duquet \& J.A.P. Day (Eds.), Kinanthropometry IV (pp. 19-41). London: E. and F.N. Spon.

Maynard, L.M., Wisemandle, W., Roche, A.F., Chumlea, W.C., Guo, S.S., \& Siervogel, R.M. (2001). Childhood body composition in relation to body mass index. Pediatrics, $107,344-350$.

McClelland, G.H., \& Judd, C.M. (1993). Statistical difficulties of detecting interactions and moderator effects. Psychological Bulletin, 114, 376-390.

Moerman, M.L. (1982). Growth of the birth canal in adolescent girls. American Journal of Obstetrics and Gynecology, 143, 528-532.

Neggers, Y., Goldenberg, R.L., Cliver, S.P., Hoffman, H.J., \& Cutter, G.R. (1995). The relationship between maternal and neonatal anthropometric measurements in term newborns. Obstetrics and Gynecology, 85, 192-196.

Nindl, B.C., Scoville, C.R., Sheehan, K.M., Leone, C.D., \& Mello, R.P. (2002). Gender differences in regional body composition and somatotrophic influences of IGF-I and leptin. Journal of Applied Physiology, 92, 1611-1618.

Norgan, N.G. (1990). Body mass index and body energy stores in developing countries. European Journal of Clinical Nutrition, 44(suppl), 79-84.

Norgan, N.G. (1997). The beneficial effects of body fat and adipose tissue in humans. International Journal of Obesity, 21, 738-746.

Olsson, M., Shine, R., Wapstra, E., Ujvari, B., \& Madsen, T. (2002). Sexual dimorphism in lizard body shape: the roles of sexual selection and fecundity selection. Evolution, 56, 1538-1542.

Pagel, M. (1994). The evolution of conspicuous oestrous advertisement in Old World monkeys. Animal Behavior, 47, 1333-1341. 
Plavcan, J.M. (2001). Sexual dimorphism in primate evolution. Yearbook of Physical Anthropology, 44, 25-53.

Plavcan, J.M. (2012). Sexual size dimorphism, canine dimorphism, and male-male competition in primates: Where do humans fit in? Human Nature, 23, 45-67.

Pomeroy, E., Stock, J.T., Stanojevic, S., Miranda, J.J., Cole, T.J., \& Wells, J.C.K. (2012). Trade-offs in relative limb length among Peruvian children: Extending the thrifty phenotype hypothesis to limb proportions. PLOS ONE, 7, e51795.

Pond, C.M. (1978). Morphological aspects and the ecological and mechanical consequences of fat deposition in wild vertebrates. Annual Review of Ecology and Systematics, 9, 519-570.

Pond, C.M. (1998). The Fats of Life. Cambridge: Cambridge University Press.

Puts, D.A. (2010). Beauty and the beast: Mechanisms of sexual selection in humans. Evolution and Human Behavior, 31, 157-175.

R Core Team. (2016). R: A language and environment for statistical computing. R Foundation for Statistical Computing, Vienna, Austria. URL https://www.R-project.org/.

Rebuffé-Scrive, M., Enk, L., Crona, N., Lönnroth, P., Abrahamsson, L., Smith, U., \& Björntorp, P. (1985). Fat cell metabolism in different regions in women: Effect of menstrual cycle, pregnancy and lactation. Journal of Clinical Investigations, 75, 1973-1976.

Riggs, B.L., Khosla, S., \& Melton, L.J. (2002). Sex steroids and the construction and conservation of the adult skeleton. Endocrine Reviews, 23, 279-302.

Rodríguez, G., Samper, M.P., Ventura, P., Moreno, L.A., Olivares, J.L., \& Perez-González, J.M. (2004). Gender differences in newborn subcutaneous fat distribution. European Journal of Pediatrics, 163, 457-461.

Rogol, A.D., Roemmich, J.N., \& Clark, P.A. (2002). Growth at puberty. Journal of Adolescent Health, 31, 192-200.

Santosa, S., \& Jensen, M.D. (2014). Sex and sex steroids: impact on the kinetics of fatty acids underlying body shape. Hormone Molecular Biology and Clinical Investigation, 20, 15-23.

Schultz, A.H. (1949). Sex differences in the pelves of primates. American Journal of Physical Anthropology, 7, 401-424.

Shih, R., Wang, Z., Heo, M., Wang, W., \& Heymsfield, S.B. (2000). Lower limb skeletal muscle mass: development of dual-energy X-ray absorptiometry prediction model. Journal of Applied Physiology, 89, 1380-1386. 
Shen, W., Punyanitya, M., Silva, A.M., Chen, J., Gallagher, D., Sardinha, L.B., Allison, D.B., \& Heymsfield, S.B. (2009). Sexual dimorphism of adipose tissue distribution across the lifespan: A cross-sectional whole-body magnetic resonance imaging study. Nutrition \& Metabolism, 6, 17.

Shungin, D., Winkler, T.W., Croteau-Chonka, D.C., Ferreira, T., Locke, A.E., Mägi, R., ... Mohlke, K.L. (2015). New genetic loci link adipose and insulin biology to body fat distribution. Nature, $518,187-196$.

Singh, D. (1993). Adaptive significance of female physical attractiveness: Role of waist-to-hip ratio. Journal of Personality and Social Psychology, 65, 293-307.

Stearns, S. (1992). The Evolution of Life Histories. Oxford: Oxford University Press.

Swami, V., \& Tovée, M.J. (2005). Male physical attractiveness in Britain and Malaysia: a crosscultural study. Body Image, 2, 383-393.

Tague, R.G. (1992). Sexual dimorphism in the human bony pelvis, with a consideration of the Neanderthal pelvis from Kebara Cave, Israel. American Journal of Physical Anthropology, 88, 121.

Tague, R.G. (2005). Big-bodied males help us recognize that females have big pelves. American Journal of Physical Anthropology, 127, 392-405.

Tanner, J.M. (1965). The relationship of puberty to other maturity indicators and body composition in man. Symposia of the Society for the Study of Human Biology, 6, 211.

Tanner, J.M. (1990). Foetus into Man: Physical Growth from Conception to Maturity. Cambridge: Harvard University Press.

Teder, T., \& Tammaru, T. (2005). Sexual size dimorphism within species increases with body size in insects. Oikos, 108, 321-334.

Tracer, D.P. (2002). Somatic versus reproductive energy allocation in Papua New Guinea: Life history theory and public health policy. American Journal of Human Biology, 14, 621-626.

Treleaven, P.C. (2004). Sizing us up. IEEE Spectrum, 41, 28-31.

Trivers, R.L. (1972). Parental investment and sexual selection. In B. Campbell (Ed.), Sexual selection and the descent of man 1871-1971 (pp. 136-179). Chicago: Aldine.

Wang, J., Gallagher, D., Thornton, J.C., Yu, W., Horlick, M., \& Pi-Sunyer, F.X. (2006). Validation of a 3-dimensional photonic scanner for the measurement of body volumes, dimensions, and percentage body fat. American Journal of Clinical Nutrition, 83, 809-816. 
Wells, J.C.K. (2006). The evolution of human fatness and susceptibility to obesity: An ethological approach. Biological Reviews, 81, 183-205.

Wells, J.C.K. (2007). Sexual dimorphism of body composition. Best Practice \& Research: Clinical Endocrinology \& Metabolism, 21, 415-430.

Wells, J.C.K., Treleaven, P., \& Cole, T.J. (2007). BMI compared with 3-dimensional body shape: The UK National Sizing Survey. American Journal of Clinical Nutrition, 85, 419-425.

Wells, J.C.K., Cole, T.J., \& Treleaven, P. (2008). Age-variability in body shape associated with excess weight: The UK National Sizing Survey. Obesity, 16, 435-441.

Wells, J.C.K. (2010). The Evolutionary Biology of Human Body Fatness: Thrift and Control. Cambridge: Cambridge University Press.

Wells, J.C.K., Griffin, L., \& Treleaven, P. (2010). Independent changes in female body shape with parity and age: A life-history approach to female adiposity. American Journal of Human Biology, $22,456-462$.

Wells, J.C.K., Charoensiriwath, S., \& Treleaven, P. (2011). Reproduction, aging, and body shape by 3-dimensional photonic scanning in Thai men and women. American Journal of Human Biology, 23, 291-298.

Wells, J.C.K. (2012). Sexual dimorphism in body composition across human populations: Associations with climate and proxies for short- and long-term energy supply. American Journal of Human Biology, 24, 411-419.

Wells, J.C.K., Williams, J.E., Chomtho, S., Darch, T., Grijalva-Eternod, C., Kennedy, K., Haroun, D., Wilson, C., Cole, T.J., \& Fewtrell, M.S. (2012a). Body-composition reference data for simple and reference techniques and a 4-component model: A new UK reference child. American Journal of Clinical Nutrition, 96, 1316-1326.

Wells, J.C.K., Treleaven, P., \& Charoensiriwath, S. (2012b). Body shape by 3D photonic scanning in Thai and UK adults: comparison of national sizing surveys. International Journal of Obesity, $36,148-154$.

Wells, J.C.K. (2013). Commentary: The thrifty phenotype and the hierarchical preservation of tissues under stress. International Journal of Epidemiology, 42, 1223-1227.

Wells, J.C.K., \& Cortina Borja, M. (2013). Different associations of subscapular and triceps skinfold thicknesses with pathogen load: An ecogeographical analysis. American Journal of Human Biology, 25, 594-605. 
Zaadstra, B.M., Seidell, J.C., Van Noord, P.A.H., te Velde, E.R., Habbema, J.D.F., Vrieswijk, B., \& Karbaat, J. (1993). Fat and female fecundity: prospective study of effect of body fat distribution on conception rates. BMJ, 306, 484-487.

Zillikens, M.C., Yazdanpanah, M., Pardo, L.M., Rivadeneira, F., Aulchenko, Y.S., Oostra, B.A., Uitterlinden, A.G., Pols, H.A.P., \& van Duijn, C.M. (2008). Sex-specific genetic effects influence variation in body composition. Diabetologia, 51, 2233-2241.

John Wiley 23 Sons, Inc. 

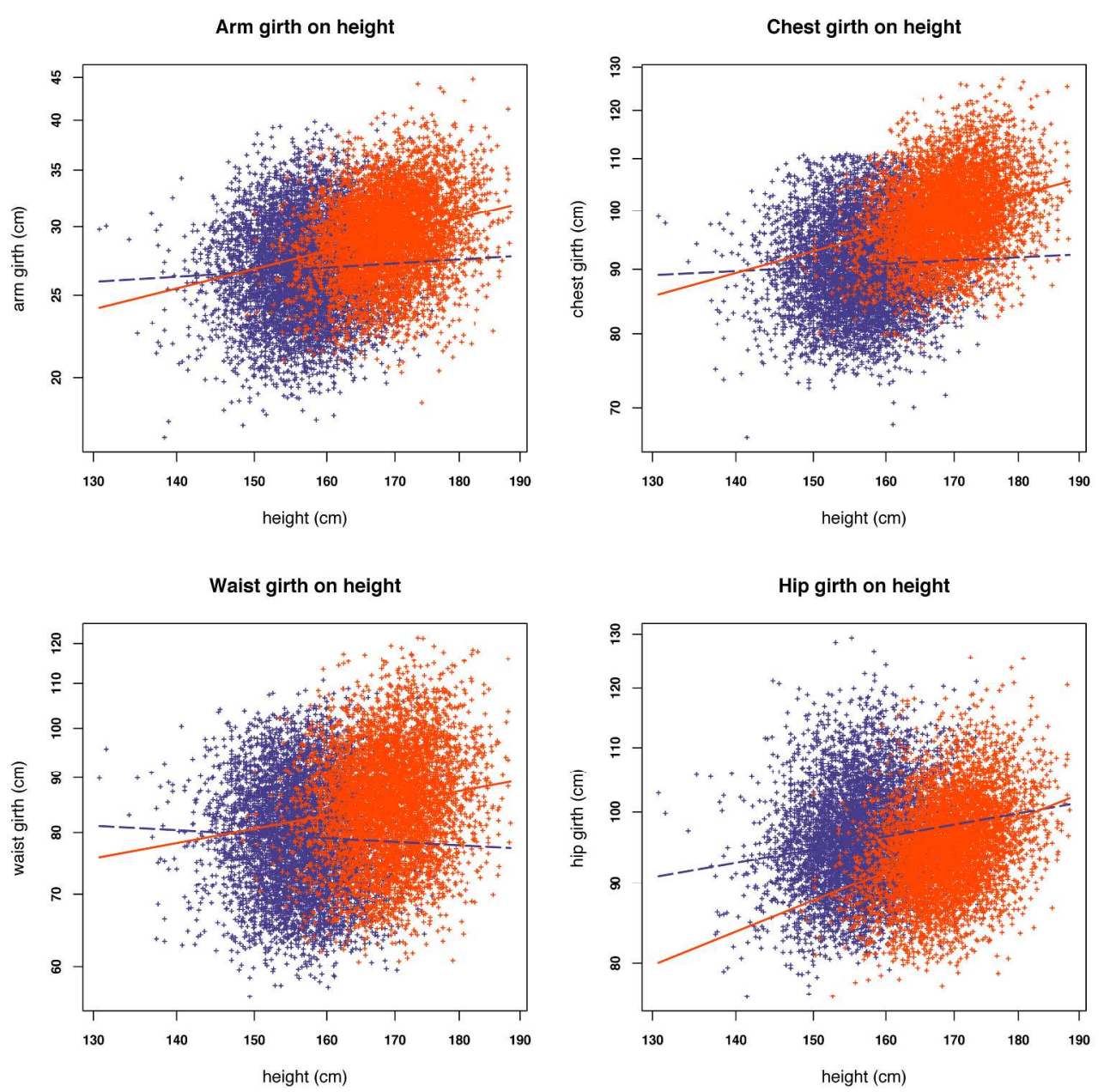

Figure 1

$254 \times 254 \mathrm{~mm}(300 \times 300$ DPI $)$

John Wiley \& Sons, Inc. 

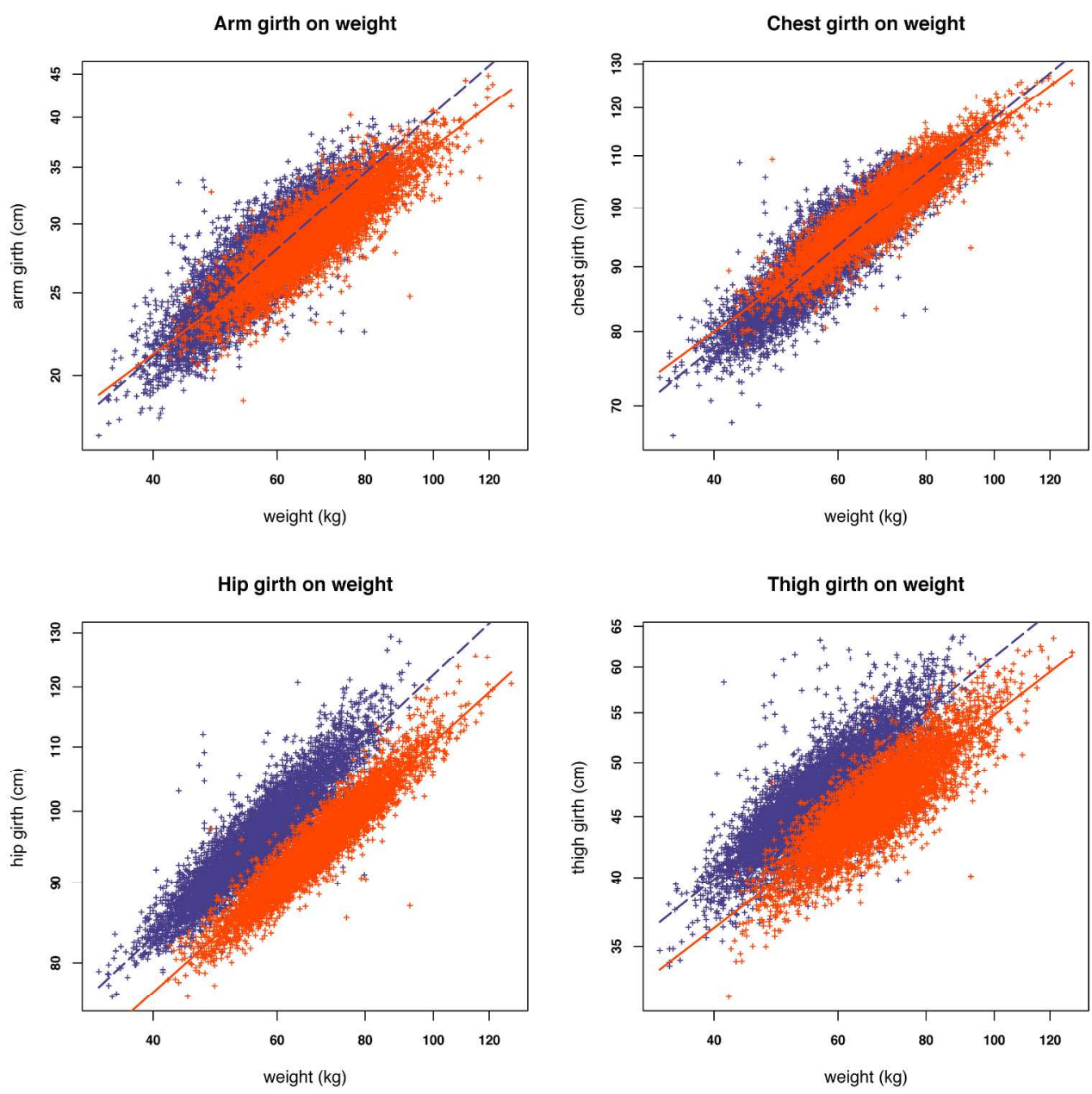

Figure 2

$254 \times 254 \mathrm{~mm}(300 \times 300$ DPI $)$

John Wiley \& Sons, Inc. 
Figure 1. Arm, chest, waist, and hip girths plotted against height in males and females. Females are dark blue, males are red-orange. Males demonstrate steeper slopes compared to females.

Figure 2. Arm, chest, hip and thigh girths plotted against weight in males and females. Females are dark blue, males are red-orange. Interaction effects are evident for arm and chest girths on weight. Similar effects are less apparent for hip and thigh plots, wherein relatively consistent sex differences are seen across the range of weight. 
Table 1. Raw anthropometric and shape statistics for males and females

\begin{tabular}{|l|c|c|c|c|}
\hline & \multicolumn{2}{|c|}{ Males $\mathrm{n}=5486$} & \multicolumn{2}{c|}{ Females $\mathrm{n}=6124$} \\
\hline & Range & Mean \pm SD & Range & Mean \pm SD \\
\hline Weight, kg & $42-129$ & $69.3 \pm 11.4$ & $33.5-98.6$ & $56.9 \pm 9.4$ \\
\hline Height, cm & $148.5-188.4$ & $169.3 \pm 5.9$ & $130.7-177.1$ & $156.7 \pm 5.7$ \\
\hline BMI, kg/m ${ }^{2}$ & $15.2-40$ & $24.2 \pm 3.6$ & $15.1-38.2$ & $23.2 \pm 3.7$ \\
\hline Head, cm & $43-65$ & $55.9 \pm 1.6$ & $42-60$ & $53.7 \pm 1.5$ \\
\hline Arm, cm & $18.7-44.8$ & $29.5 \pm 3.3$ & $17-39.8$ & $27 \pm 3.6$ \\
\hline Chest, cm & $78-127.2$ & $99.7 \pm 7.2$ & $66.2-111$ & $91 \pm 7.6$ \\
\hline Waist, cm & $60.6-121.4$ & $85.6 \pm 10$ & $56.2-110.8$ & $79.8 \pm 9.4$ \\
\hline Hip, cm & $76.1-125.6$ & $95.2 \pm 6.6$ & $76.1-129.3$ & $96.1 \pm 7.2$ \\
\hline Thigh, cm & $31.7-63.5$ & $46.3 \pm 4$ & $33.7-63.7$ & $47 \pm 4.4$ \\
\hline Knee, cm & $29.5-48$ & $37.5 \pm 2.4$ & $28.3-49.7$ & $36.9 \pm 3$ \\
\hline Calf, cm & $27.5-49.6$ & $36.6 \pm 3$ & $25.3-48$ & $34.9 \pm 3$ \\
\hline
\end{tabular}


Table 2. Raw anthropometric and shape statistics ( $\bar{x} \pm$ SD) stratified by sex and age

\begin{tabular}{|c|c|c|c|c|c|c|c|c|c|c|c|c|}
\hline & & Weight & Height & BMI & Head & Arm & Chest & Waist & Hip & Thigh & Knee & Calf \\
\hline & $n$ & $\mathrm{~kg}$ & $\mathrm{~cm}$ & $\mathrm{~kg} / \mathrm{m}^{2}$ & $\mathrm{~cm}$ & $\mathrm{~cm}$ & $\mathrm{~cm}$ & $\mathrm{~cm}$ & $\mathrm{~cm}$ & $\mathrm{~cm}$ & $\mathrm{~cm}$ & $\mathrm{~cm}$ \\
\hline \multicolumn{13}{|l|}{ Males } \\
\hline \multicolumn{13}{|l|}{ Age (y) } \\
\hline $21-30$ & 1454 & $67.1 \pm 11.9$ & $171.3 \pm 5.7$ & $22.8 \pm 3.6$ & $56.0 \pm 1.7$ & $28.6 \pm 3.6$ & $97.6 \pm 7.3$ & $80.6 \pm 9.8$ & $93.9 \pm 7.1$ & $46.6 \pm 4.3$ & $37.3 \pm 2.5$ & $36.4 \pm 3.1$ \\
\hline $31-40$ & 1289 & $71.2 \pm 12.2$ & $170.2 \pm 5.9$ & $24.5 \pm 3.7$ & $56.0 \pm 1.7$ & $30.0 \pm 3.4$ & $100.9 \pm 7.3$ & $85.8 \pm 9.9$ & $96.2 \pm 6.8$ & $47.5 \pm 4.1$ & $37.9 \pm 2.5$ & $37.1 \pm 3.1$ \\
\hline $41-50$ & 1195 & $70.8 \pm 10.7$ & $169.1 \pm 5.8$ & $24.7 \pm 3.3$ & $55.9 \pm 1.6$ & $30.0 \pm 3.1$ & $101.1 \pm 6.7$ & $87.5 \pm 9.1$ & $96.0 \pm 6.1$ & $46.6 \pm 3.6$ & $37.6 \pm 2.3$ & $36.9 \pm 2.8$ \\
\hline $51-60$ & 777 & $70.1 \pm 10.4$ & $167.7 \pm 5.4$ & $24.9 \pm 3.2$ & $55.9 \pm 1.5$ & $30.0 \pm 3.1$ & $100.6 \pm 6.9$ & $88.8 \pm 9.0$ & $95.8 \pm 6.1$ & $45.7 \pm 3.4$ & $37.5 \pm 2.3$ & $36.6 \pm 2.7$ \\
\hline $61-70$ & 583 & $67.8 \pm 9.6$ & $166.2 \pm 5.1$ & $24.5 \pm 3.0$ & $55.5 \pm 1.6$ & $29.5 \pm 2.8$ & $99.0 \pm 6.3$ & $89.1 \pm 8.5$ & $94.9 \pm 5.8$ & $44.5 \pm 3.3$ & $37.3 \pm 2.2$ & $35.8 \pm 2.5$ \\
\hline$\geq 71$ & 188 & $63.8 \pm 10.7$ & $164.4 \pm 5.3$ & $23.6 \pm 3.7$ & $55.0 \pm 1.5$ & $28.5 \pm 3.4$ & $96.1 \pm 7.5$ & $87.7 \pm 10.4$ & $93.1 \pm 6.8$ & $43.0 \pm 3.7$ & $36.8 \pm 2.3$ & $34.5 \pm 2.7$ \\
\hline \multicolumn{13}{|l|}{ Females } \\
\hline \multicolumn{13}{|l|}{ Age (y) } \\
\hline $21-30$ & 1614 & $53.3 \pm 9.3$ & $158.8 \pm 5.5$ & $21.1 \pm 3.4$ & $53.7 \pm 1.5$ & $25.0 \pm 3.3$ & $86.8 \pm 6.9$ & $73.8 \pm 8.4$ & $93.1 \pm 7.0$ & $46.1 \pm 4.5$ & $36.4 \pm 2.9$ & $34.3 \pm 3.0$ \\
\hline $31-40$ & 1348 & $57.0 \pm 9.3$ & $157.7 \pm 5.1$ & $22.9 \pm 3.5$ & $53.7 \pm 1.6$ & $26.8 \pm 3.4$ & $90.6 \pm 7.1$ & $78.4 \pm 8.5$ & $96.1 \pm 6.8$ & $47.7 \pm 4.2$ & $37.0 \pm 2.9$ & $35.2 \pm 3.0$ \\
\hline $41-50$ & 1250 & $58.8 \pm 9.0$ & $156.8 \pm 5.3$ & $23.9 \pm 3.5$ & $53.7 \pm 1.5$ & $27.8 \pm 3.4$ & $92.7 \pm 7.0$ & $81.2 \pm 8.4$ & $97.4 \pm 6.6$ & $47.9 \pm 4.1$ & $37.2 \pm 3.0$ & $35.5 \pm 3.0$ \\
\hline $51-60$ & 860 & $59.6 \pm 8.9$ & $155.1 \pm 5.3$ & $24.8 \pm 3.5$ & $53.7 \pm 1.5$ & $28.4 \pm 3.4$ & $94.2 \pm 7.3$ & $84.6 \pm 8.4$ & $98.3 \pm 7.0$ & $47.3 \pm 4.2$ & $37.1 \pm 3.0$ & $35.2 \pm 2.9$ \\
\hline $61-70$ & 835 & $58.3 \pm 8.7$ & $153.8 \pm 5.5$ & $24.6 \pm 3.4$ & $53.5 \pm 1.4$ & $28.5 \pm 3.3$ & $93.6 \pm 7.2$ & $85.4 \pm 8.3$ & $97.9 \pm 7.4$ & $46.1 \pm 4.3$ & $37.1 \pm 3.2$ & $34.6 \pm 3.0$ \\
\hline$\geq 71$ & 217 & $55.6 \pm 8.6$ & $151.7 \pm 5.2$ & $24.1 \pm 3.5$ & $53.2 \pm 1.6$ & $27.6 \pm 3.5$ & $92.3 \pm 7.7$ & $84.7 \pm 8.7$ & $96.7 \pm 7.5$ & $44.2 \pm 4.2$ & $36.5 \pm 3.3$ & $33.8 \pm 3.1$ \\
\hline
\end{tabular}


Table 3. Correlation coefficients of height and weight with eight body girths in males and females

\begin{tabular}{|c|l|l|l|l|l|l|l|l|}
\hline & Head & Arm & Chest & Waist & Hip & Thigh & Knee & Calf \\
\hline Height & & & & & & & & \\
\hline Males & 0.34 & 0.23 & 0.27 & 0.13 & 0.34 & 0.35 & 0.42 & 0.30 \\
\hline Females & 0.28 & 0.05 & 0.04 & -0.04 & 0.14 & 0.16 & 0.24 & 0.18 \\
\hline & & & & & & & & \\
\hline Weight & & & & & & & & \\
\hline Males & 0.47 & 0.87 & 0.92 & 0.88 & 0.95 & 0.85 & 0.86 & 0.86 \\
\hline Females & 0.36 & 0.87 & 0.88 & 0.85 & 0.91 & 0.83 & 0.78 & 0.83 \\
\hline
\end{tabular}

Males: $n=5486$; females: $n=6124$

All data log-transformed; all correlations significant at $p \leq 0.002$ 
Table 4. Multivariable log-log regression analysis of girths on height, sex, and sex-height interaction, adjusted for age, salary and number of children

\begin{tabular}{|l|c|c|c|c|c|c|c|}
\hline & $\begin{array}{c}\text { Height } \\
b\end{array}$ & $95 \% \mathrm{Cl}$ & $\begin{array}{c}\text { Male sex } \\
b\end{array}$ & $95 \% \mathrm{Cl}$ & $\begin{array}{c}\text { Male sex-height } \\
\text { interaction } \\
b\end{array}$ & $95 \% \mathrm{Cl}$ & $R^{2}$ \\
\hline Head & 0.247 & $0.23,0.26$ & 0.021 & $0.019,0.022$ & 0.072 & $0.04,0.1$ & 0.40 \\
\hline Arm & 0.819 & $0.76,0.88$ & 0.026 & $0.019,0.033$ & 0.544 & $0.43,0.66$ & 0.22 \\
\hline Chest & 0.519 & $0.48,0.56$ & 0.049 & $0.046,0.054$ & 0.453 & $0.38,0.53$ & 0.34 \\
\hline Waist & 0.629 & $0.57,0.69$ & 0.022 & $0.016,0.027$ & 0.538 & $0.43,0.65$ & 0.26 \\
\hline Hip & 0.627 & $0.59,0.66$ & -0.059 & $-0.063,-0.056$ & 0.369 & $0.30,0.44$ & 0.13 \\
\hline Thigh & 0.571 & $0.52,0.62$ & -0.061 & $-0.066,-0.056$ & 0.448 & $0.36,0.54$ & 0.08 \\
\hline Knee & 0.736 & $0.70,0.77$ & -0.039 & $-0.044,-0.036$ & 0.214 & $0.14,0.28$ & 0.14 \\
\hline Calf & 0.577 & $0.53,0.62$ & -0.001 & $-0.005,0.004$ & 0.285 & $0.20,0.37$ & 0.14 \\
\hline Weight & 1.975 & $1.90,2.05$ & 0.040 & $0.032,0.048$ & 0.795 & $0.65,0.94$ & 0.41 \\
\hline
\end{tabular}

$\mathrm{n}=11610(\mathrm{f}=6124)$

Girths and height are mean-centered and natural log-transformed

See Supporting Information online for table including outcomes for age, salary and number of children $p$-value for 'Male sex' coefficient in calf model non-significant; all other coefficients highly significant at $p<0.0001$ With the interaction term included, 'Height' effect is for females; the sum of 'Height' and 'Male sex-height interaction' is the height effect for males 
Table 5. Multivariable log-log regression analysis of girths on weight, sex, and sex-weight interaction, adjusted for age, salary and number of children

\begin{tabular}{|l|c|c|c|c|c|c|c|}
\hline & $\begin{array}{c}\text { Weight } \\
b\end{array}$ & $95 \% \mathrm{Cl}$ & $\begin{array}{c}\text { Male sex } \\
b\end{array}$ & $95 \% \mathrm{Cl}$ & $\begin{array}{c}\text { Male sex-weight } \\
\text { interaction } \\
b\end{array}$ & $95 \% \mathrm{Cl}$ & $R^{2}$ \\
\hline Head & 0.075 & $0.072,0.078$ & 0.025 & $0.024,0.026$ & 0.018 & $0.012,0.023$ & 0.46 \\
\hline Arm & 0.652 & $0.645,0.659$ & -0.034 & $-0.037,-0.032$ & -0.077 & $-0.091,-0.064$ & 0.80 \\
\hline Chest & 0.424 & $0.420,0.428$ & 0.009 & $0.008,0.011$ & -0.035 & $-0.043,-0.028$ & 0.86 \\
\hline Waist & 0.604 & $0.598,0.609$ & -0.045 & $-0.047,-0.043$ & 0.058 & $0.047,0.069$ & 0.85 \\
\hline Hip & 0.409 & $0.406,0.412$ & -0.089 & $-0.090,-0.088$ & -0.014 & $-0.20,-0.008$ & 0.86 \\
\hline Thigh & 0.474 & $0.468,0.479$ & -0.107 & $-0.109,-0.105$ & -0.041 & $-0.052,-0.031$ & 0.74 \\
\hline Knee & 0.367 & $0.362,0.371$ & -0.054 & $-0.055,-0.052$ & -0.054 & $-0.064,-0.045$ & 0.66 \\
\hline Calf & 0.442 & $0.437,0.447$ & -0.041 & $-0.042,-0.039$ & -0.025 & $-0.035,-0.015$ & 0.75 \\
\hline
\end{tabular}

$\mathrm{n}=11610(\mathrm{f}=6124)$

Girths and weight are mean-centered and natural log-transformed

See Supporting Information online for table including outcomes for age, salary and number of children

All coefficients highly significant at $p<0.0001$

With the interaction term included, 'Weight' effect is for females; the sum of 'Weight' and 'Male sex-weight interaction' is the weight effect for males 